\title{
THE INCIDENCE OF POSTOPERATIVE JAUNDICE WITH SPECIAL REFERENCE TO HALOTHANE*
}

\author{
J C HENDERSON, $\mathbb{A}, M D, C M, D A, A N D$ \\ R A GoRDON, BSC, MD, FRCP(C), F F A R S
}

A NUMBER OF PUBLICATIONS in the recent literature have drawn attention to hepatic necrosis in patients who have been anaesthetized with halothane ${ }^{1-15}$ Ir these reports halothane has been indicted as the causative agent Reaction to these reports has varied from the dogmatic attitude that haloil hane should be abandoned as an anaesthetic agent to blind insistence that halothane cannot be responsible for hepatic damage These positions obviously represent extremes which so far fail to be supported by facts It is evident that the whole question of hepatic damage and hepatic fallure following anaesthesia and operation requires careful examination Considering the current controversy concerning the role of halothane in the production of hepatic damage, such an exarnination should, of course, have particular reference to the 1 ole which this drug may play in producing hepatic fallure

The approach to this problem which immediately suggests itself to most people is the examination of hospital records to determine whether the use of halothane has in fact been associated with an increase in clinical evidence of hepatic damage or death from hepatic fallure It is appreciated that such a study will neithei prove nor disprove the contention that halothane produces hepatic damage It is reasonable to believe however, that, providing all the patients who have shown clmical evidence of hepatic damage in the postoperative period can be identified, and providing that the statistical sample is large enough, the question as to whether the use of halothane is more likely to produce hepatic damage than the use of other agents and techniques may be answered with some certainty We are aware that many factors associated with the treatment of surgical patients may result in hepatic damage, and that there is at the present tume no possible method of ruling out intercurrent vural infections of the liver

In the hope that we might provide a reasonable answer to this primary question, we have examined the records of those patients in the Toronto General Hospital who have developed clmical jaundice in the postoperative period during the vears 1953 to 1956 , when no halothane was used, and during the period 1960 to 1963, when a large proportion of the generall anaesthetics administered to surgical patients employed halothane as one of the agents

\section{METHOD}

The primary problem in retrospective studies of this type is the location and identification of the patients to be included in the study Many approaches to a

From the Department of Anaesthesia, University of Toronto and The Toronto General Hospital 
solution of this problem have been suggested In this study we have attempted to locate all patients who developed clinical jaundice in the postoperative period by reference to the records of the biochenncal laboratory We have examined the records of all the patients who have been reported to have a serum bulirubin greater than 15 Vandenburg units While we cannot guarantee that this will identify every patient in our hospital who has had clinical jaundice, we are reasonably certain that the number who will be missed by this method is extremely small The record of each patient has been examined to determine whether or not he had an anaesthetic, and our present report is based on the records of those patients who had, and whose serum bilurubin was $15 \mathrm{mg}$ per cent or higher postoperatively We have excluded all patients who were jaundiced at the time of operation, all obstetrical patients, and all patients who had regional anaesthesia Our report, therefore, is based on those patients who were not jaundiced at the tume of operation, who developed jaundice postoperatively, and who received general anaesthetics for surgical procedures of all types

\section{REsUlTs}

Durng the penods of study, 1953-56 and 1960-63, a total of 92,920 general anaesthetics were administered at the Tolonto General Hospital. There were 44,609 administered in the initial period and 48,311 in the latter, of which 21,461 or 44 per cent were with halothane

A total of 250 cases of postoperative jaundice ( Table I) was found on reviewing

\begin{tabular}{cccc} 
TABLE I & \\
Postoperative Jaundice & after & General Anaesthesia \\
\hline $\begin{array}{c}\text { No of } \\
\text { anaesthetics }\end{array}$ & $\begin{array}{c}\text { Cases of } \\
\text { jaundice }\end{array}$ & $\begin{array}{c}\text { Incidence } \\
\text { per } 1000\end{array}$ \\
\hline $1953-56$ & 44,609 & 49 & 11 \\
$1960-63$ & 88,311 & 201 & 42 \\
\hline
\end{tabular}

the medical records for these patients, 49 occurring during the $1953-56$ period and 201 in the 1960-63 period This gives an incidence of 11 , per thousand for the first period and 42 per thousand general anaesthetics adrinistered for the second Of the 201 cases from 1960 to 1963 (Table II) 88 had halothane while

TABLE II

Postoperative Jaundice after General Anacsthesia, $1960-63$

\begin{tabular}{lccc}
\hline Agents & $\begin{array}{c}\text { No of } \\
\text { anaesthetics }\end{array}$ & $\begin{array}{c}\text { Cáses of } \\
\text { jaundice }\end{array}$ & $\begin{array}{c}\text { Inctdence } \\
\text { per 10b0 }\end{array}$ \\
\hline Halothane & 21,461 & 88 & 41 \\
Other agents & 26,850 & 113 & 42 \\
\hline
\end{tabular}

113 had other agents, an mcidence of 41 and 42 per thousand respectuvely The moldence for those anaesthetized with agents other than halo(hane (Table III) 
TABLE III

Postoperative Jaundice after Genekal Alnaesthesia, 1960-63

\begin{tabular}{lc|c}
\hline $\begin{array}{c}\text { Agents other } \\
\text { than halothane }\end{array}$ & $\begin{array}{c}\text { Cases of } \\
\text { jaundice }\end{array}$ & $\begin{array}{c}\text { Incidence } \\
\text { per 1000 }\end{array}$ \\
\hline Nitrous oxide trelaxant & 98 & 41 \\
Ether & 1 & 38 \\
Cyclopropane & 12 & 74 \\
\hline
\end{tabular}

was 41 per thousand for nitrous oxide with or without relaxants, 38 per thousand for ether, and 74 per thousand for cyclopropane

The onset of jaundice occurred within 14 days in over 80 per cent of the cases in both periods, regardless of the agents used (Table IV) Eighty per cent of all the

TABLE IV

Postoperative Jaundice after General Anaesthesia

\begin{tabular}{|c|c|c|c|}
\hline \multirow{2}{*}{$\begin{array}{c}\text { Time } \\
\text { (days) }\end{array}$} & \multirow{2}{*}{$\begin{array}{c}1953-56 \\
(\%)\end{array}$} & \multicolumn{2}{|c|}{$1960-63(\%)$} \\
\hline & & Halothane & Other agents \\
\hline $0-7$ & 60 & $5 !$ & 81 \\
\hline 8-14 & 26 & 21 & 10 \\
\hline $15-21$ & 一 & 7 & 4 \\
\hline $22-28$ & - & 6 & 1 \\
\hline$>28$ & 14 & 8 & 4 \\
\hline
\end{tabular}

cases had temperatures of $1005^{\circ} \mathrm{F}$ or greater within the first postoperative week. Blood transfusions were administered to 70 per cent of those in the 1953-56 period and to 88 per cent in the 1960-63 period In this latter penod 85 per cent of the group anaesthetized with halothane and 91 per cent of those anaesthetized with other agents received blood In addition, many of those who did not receive blood were given drugs such as penicillin, tetracycline, and chlorpromazine, which have been shown to cause jaundice

The mortality rate for the period 1953-56 was 37 per cent and for 1960-63, 25 per cent (Table V) Of the 88 patients who had jaundice after receiving

TABLE V

Postoperative Jaundice after General Anaesthesia, MORTALITY RATES

\begin{tabular}{lcc|c}
\hline \hline & $\begin{array}{c}\text { Cases of } \\
\text { jaundice }\end{array}$ & Deaths & $\%$ \\
\hline $1953-56$ & 49 & 18 & 37 \\
$1960-63$ & 201 & 51 & 25 \\
\hline
\end{tabular}

halothane (Table VI), 23 died, one quarter within the first week postoperatively Twenty-eight deaths occurred in the remanning 113 cases, one third of these within the first postoperative week The case mortality rale was therefore 26 per cent for those who had received halothane, and 25 per cent for those anaesthetzzed with other agents 
TABLE VI

Postoperative Jaundice alter General ANaesthesia, Mortality Flates 1960-63

\begin{tabular}{lrcc}
\hline \hline \multicolumn{1}{c}{ Agents } & $\begin{array}{r}\text { Cases of } \\
\text { jaundice }\end{array}$ & Deaths & $\%$ \\
\hline Halothane & 88 & 23 & 26 \\
Other agents & 113 & 28 & 25 \\
\hline
\end{tabular}

The causes of death that could be ascertained as accurately as possible from the charts and post-mortem findings were varied (Table VII) Five deaths due to

TABLE VII

\begin{tabular}{lcc}
$\begin{array}{c}\text { Postoperative Jaundice After General Anafsthesia } \\
\text { Causes OF DeATH } \\
1960-63\end{array}$ \\
\hline
\end{tabular}

hepatic fallure occurred in those anaesthetized with halothane, three in the nonhalothane group Of these, primary carcinoma with widespread secondaries was found in one, and four had proven cirrhosis preoperatively There remained three cases, one in the halothane and two in the non-halothane group, which could not be explained (Table VIII)

\section{TABLE VIII}

\begin{tabular}{lcc}
$\begin{array}{c}\text { Postoperative Jaundice after Gencral Anaesthifsia, } \\
\text { Hepatic Causes of Death } \\
1960-63\end{array}$ & \\
\hline & Halothane & Other agents \\
\hline Carcinoma & 1 & - \\
Cirrhosis & 3 & 1 \\
Unexplained & 1 & 2 \\
\hline
\end{tabular}

\section{Disicussion}

The increase in uncidence of postopelative jaundice from 11 to 42 per thousand general anaesthetics administered during the two periods studied can possibly be explained by several factors

One must consider the changing operative pattern More complicated and prolonged procedures, necessitatung the administration of blood and drugs more frequently and in greater quantities, are being carried out Heart-lung and neuro- 
logical procedures accounted for over 12 per cent and 10 per cent respectively, of the cases during 1960-63, in contrast to 0 and 2 per cent in the 1953-56 series

The chance of transmitting the virus of serum hepatitis accidentally has been reported to vary from 1 per cent for those receiving one unit of blood to 3 per cent for those receiving four units ${ }^{16}$ A recent Japanese report estimates that 645 per cent of their blood transfusions transmit the virus, with an incubation period varying from 2 to 11 weeks Their incidence of hepatitis was 38 per cent for those receiving 200 to $800 \mathrm{cc}$ of blood, and 58 per cent for 1000 to $1600 \mathrm{cc}$, only 10 per cent of which developed clinical jaundice ${ }^{17}$

The threefold increase in incidence of infectious hepatitis, estimated on the basis of the number of reported cases, ${ }^{18}$ for the $1953-56$ to $1960-63$ periods, no doubt has a contributing role as well No method is currently avallable to separate infectious hepatitis from serum hepatitis

Other factors that must be considered in the production of postoperative liver damage are the direct and indurect consequences of trauma These consist of injury to the bile ducts or hepatic blood vessels, prolonged retraction upon the liver, or secondary to pancreatic necrosis that may complicate upper abdominal surgery Traction alone upon upper abdominal structures can dimmish hepatic blood flow by 50 per cent, thus leading to hepatic damage Prolonged shock, with or without the excessive use of vasopressors, has been noted to cause centiolobular necrosis All these factors may precipitate livel farlure, especially in cases where disease of the liver already exists

The effect of drugs on the liver is assuming ever increasing importance as a possible causative factor in the production of hepatic damage and jaundice These drugs (and over 70 have been incriminated) include many of the commonly used antibiotıcs, sedatives, antidepressants, phenothiazines,| and anticoagulants, many of these are used extensively in surgical patients pre-- and post-operatively

Of the anaesthetic agents commonly used today, none comes under Klatskn's definition of a hepatotoxin ${ }^{19}$ Yet, cyclopropane in our study and in that of Allen and Metcalf ${ }^{20}$ had a higher association with postoperative jaundice than the other agents, 1 e halothane, nitrous oxide, and ether No one would condemn cyclopiopane on this basis alone

The difference in incidence of postoperative jaundice in patients anaesthetized with halothane and with other agents is not statistically significant This does not necessanly mean that there may be no direct relationshup between halothane and hepatic necrosis, but it does give less support to those who would associate the two

\section{SUMMARY}

A retrospective study of 250 cases of postoperative jaundice following the administration of 92,920 general anaesthetics during the two periods 1953-56 and 1960-63 at the Toronto General Hospital revealed a marked increase in the over-all incidence, but no significant difference between those anaesthetized with halothane and those anaesthetzed with other agents 


\section{RÉSUMMé}

Rétrospectivement, nous avons fait une étude de 250 cas d'ictère postopératorre à la surte de 92920 anesthésies générales administrées à l'hôpital Toronto General L'étude a porté sur deux périodes la première, de 1953 à 1956, la seconde, de 1960 à 1963

Au cours de la pıemıère période, nous n'avions pas employé d'halothane mais, au cours de la seconde pérnode, nous l'avions employé dans 44 pour cent des 48311 anesthésies régionales

La frequence de l'ictère postopératorre, au cours de la premıère pérıode (1953-1956), a été de 11 par 1000 anesthésıes et, au cours de la seconde pénode (1960-1963), de 42 par 1000 anesthésies (tableau I) Sur les 201 cas d'ictère survenus entre 1960 et 1963, 88 avarent reçu de l'halothane alors que 113 avarent reçu d'autres agents une fréquence de 41 et 42 par 1000 respectivement (tableau II) La fréquence cheż ceux qui furent anesthésiés avec d'autres agents étart de 41 par 1000 pour ceux qui avarent reçu du protoxyde avec ou sans myorésolutufs, de 38 par 1000 pour ceux qui avaıent reçu de l'éther, et de 74 par 1000 pour ceux qui avaıent reçu du cyclopropane (tableau III) Chez au-delà de 80 pour cent des cas, au cours des deux pé 1odes, l'ictère est apparu avant le $14 \mathrm{e}$ jour, quel que sort l'agent utilssé (tableau IV) Le taux de mortalité pour la pénode de 1953 à 1956 a été de 37 pour cent, et pour la période de 1960 à 1963, de 25 pour cent (tableau $V$ ) Le taux de mortalité a été de 26 pour cent chez ceux qui avarent reçu de l'halothane, et de 25 pour cent chez ceux qui avarent reçu d'autres agents (tableau VI) Les causes de la mort ont été multiples (tableau VII) L'insuffisance hépatique a été la cause de la mort chez cinq malades quı avarent reçu de l'halothane, et chez trois malades dans l'autres groupe De ceux-c1, trois cas demeurent inexpliques un, parmi le groupe de lhalothane et deux, parmi l'autre groupe (tableau VIII)

Les facteurs qui peuvent expliquer l'augmentation de la fréquence de l'ictère postopératorre de 11 à 42 par 1000 anesthésies générales, au cours des deux pérıodes étudiées, peuvent se trouver dans le changement de la façon d'opérer, le risque de transmettre accidentellement le vurus d'hépatite sérique à cause de l'usage plus fréquent des transfusions, la fréquence trois fors plus grande de lhépatite infectieuse, la possibilité de traumatisme opératoure, le choc prolongé, et l'usage d'un ou plusieurs médicaments reconnus comme susceptibles de jouer un rôle dans la production de lésions hépatiques

$\mathrm{Au}$ cours de cette étude, nous n'avons pas obsen vé de dufférence imporlante entre la fréquence de l'ictère postopératoure chez les malades anesthésiés à l'halothane et chez ceux qui furent anesthésiés avec d'autres agents

\section{REFERENCES}

1 VIRTUE, $\mathbb{R}$ W, \& PAYNE, $\mathbb{K}$ W Postoperdtuve Death after Fluothane Anesthesiology 19502 (1958)

2 Hall, Getslerr, \& Norits Case Report Anesthesiology 1990 (1958)

3 BARToN, J D M Jaundice and Halothane Lancet I 1097 (1959) 
4 Temple, L T, Cote, R. A, \& Srerwood, W E Massive Hepatic Necrosis followng General Anesthesia Anesth \& Analg 41586 (1962).

5 Bunker, J P , \& Blumenfiesd, C M Liver Necrosis after Halothane Anesthetic, Cause or Coincidence New Engl J Med 268531 (1963)

6 Lindenbaun, J, \& Leifeo, E Hepatic Necrosis Assciciated with Halothane Anesthesia New Engl J Med. 268525 (1963)

7 Brody, G L, \& SweEt, R B Halothane Anesthesia as a Possible Cause of Massive Hepatic Necrosis Anesthesiology 2429 (1963)

8 Kenbex, N C, \& HinIIARD, I M Halothane Hepatoxicity Canad M A J 89944 (1963)

9 Tonnetta, F J, \& TaMakm, H T Halothane Jaundice and Hepatoxicity J A M A 184 $658(1963)$

10 Gondon, J Jaundice Associated with Halothane Anaesthesia Anaesthesia 18299 (1963)

11 BEDDARD, J R J Jaundice after Halothane and Radiotherapy Brit Med J 21592 (1963)

12 Ashron, J W, O'ConNor, $\mathrm{K} J$, \& Williams, $G$ L Jaundice after Halothane and Radiotherapy Bnt. Med J 2811 (1963)

13 Robinson, J Fluothane and Jaundice Brit Med J 21268 (1963)

14 Chamberlanv, G Luver Damage and Halothane Anaesthesia Bnt Med J 11527 (1963)

15 Hemennerg, W J, \& Torio, I Additional Case of Halothane Hepatitis

16 Alsener, J B , \& Barger, J D Transfusion 1295 (1961)

17 Shmizu, Y, \& Kттамото, $O$ Viral Hepatitis after Blood Transfusions Gastroenterology 44740 (1963)

18 Patterns of Disease Parke, Davis and Co Ltd Publication (Mar-Apr 1963)

19 Klatsin, G Symposium on Toxic Hepatic Injury Gastroenterology 38789 (1960)

20 AllLeN, H L, \& METCAL, W D A Search for Halothane Liver Complications Anesth \& Analg 43159 (1964) 